\title{
Pragmatic Functions of Reported Speech with jako in the Old Russian Primary Chronicle
} Renee Perelmutter

University of Kansas

\begin{abstract}
This article, in an attempt to add to the growing literature on Old Russian reported speech, considers the pragmatics of jako recitativum, i.e. direct discourse introduced by the particle jako 'that, how', a multifunctional conjunction with a variety of subordinating uses. Through a detailed pragmatic and quantitative analysis of corpus data, I show that in the Old Russian Primary Chronicle, jako recitativum contrasts two conflicting points of orientation, the narrator's and the speaker's. By using the construction with jako, the narrator expresses a negative and/or distancing attitude towards the content of the speaker's utterance. The contrast between reported speech with jako and reported speech without jako is shown to be more significant than the contrast between direct and indirect discourse.
\end{abstract}

\section{Introduction $^{1}$}

In the Old Russian Primary Chronicle, or Povest' vremennykh let (PVL), reported speech plays a focal role. According to Rachel May's study of dialogue in the PVL, the chronicle revolves around speech acts; the chronicler has a keen sense of the dramatic value of quoted speech (May 1997:49). The Russian Primary Chronicle is significantly more dialogue-heavy than its contemporary, the Novgorodian chronicle ${ }^{2}$. Cross-linguistically, the introduction of direct speech is said to create a higher degree of involvement, and often expresses emotional involvement (Chafe 1982, 1994; Leech and Short 1983); reliance on dialogue lends drama and emotional immediacy to a text. Dramatic impact of direct discourse notwithstanding, its crosslinguistic significance for marking narrative peaks seems to be greatly reduced in the PVL by the fact that it is used so massively throughout the text. Reported speech in PVL is not a simple foregrounding tool, but one of the chronicler's default narrative vehicles.

In this investigation, I show that three kinds of reported speech are attested in the Russian Primary Chronicle, two of which are introduced by a multi-functional subordinating conjunction jako 'that' ${ }^{3}$. The most widespread type of reported speech is direct discourse introduced without the conjunction jako. Indirect discourse, always introduced by the conjunction jako, is extremely rare, with only six undisputed occurrences in the PVL. The third kind of reported speech is the so-called jako recitativum, i.e. direct discourse introduced by jako; this construction accounts for 
$10 \%$ of all reported speech in the PVL. Through a detailed analysis of corpus data, I show that by using the jako recitativum construction, the narrator expresses his negative or distancing stance towards the content of the reported utterance. He may also use this construction to rank speakers in order of importance.

\section{Corpus and data collection}

For my study I examined the whole text of the PVL, with entries ranging from year 906 to 1110, using Donald Ostrowski's critical edition (Ostrowski 2003), and its electronic version or the e-PVL (Birnbaum and Ostrowski 2007). The quotes follow Ostrowski's proposed best reading (paradosis), which is based on a family tree of MSS rather than a single redaction of the PVL; however, the relevant differences between redactions are noted. Examples are marked by column and line numbers as they are given in Ostrowski's critical edition (which correspond to the column and line numbers in Karskij's edition of the PVL). Quotations to mark reported speech are not attested in the MSS, but are introduced here for clarification purposes. In translations, jako is rendered as 'that'; all translations are mine, unless indicated otherwise.

I have collected examples of reported speech according to the following principles: jako recitativum was collected in all its occurrences; indirect and deixis-neutral discourse with jako was collected following three basic speech verbs, глаголати 'to say', речи 'to say' and повъдати 'to tell' 4 . This approach limits the amount of reported speech collected, but allows me to consider indirect discourse in its undoubted occurrences after speech verbs, apart from other subordinating strategies, which need to be considered separately. Thus, for example, instances of

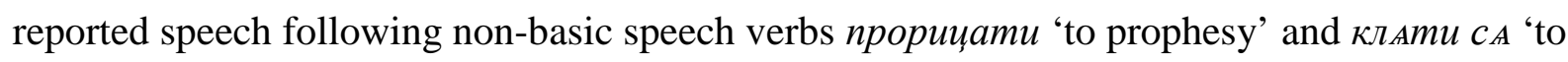
swear' were omitted, eliminating three examples of jako cum infintivum, a construction involving speech act representation which merits a separate study ${ }^{5}$.

\section{Types of reported speech and their introduction in the PVL}

The Russian Primary Chronicle has three types of reported speech, distinguished by their expression of deixis, and by the marking of the speaker's evaluative stance towards the utterance.

Expression of deixis. Deictic elements are dependent on the discourse situation; their reference point is dependent on the speaker, and on his/her position in space and time. 
The most prominent in the PVL is direct discourse with speaker-oriented deixis which is introduced without 'jako'. This type of discourse accounts for slightly more than $90 \%$ of all reported speech in the chronicle (with 682 examples out of 752 total examples of reported speech). Unmarked direct discourse is exemplified in example (1):

(1) И приъха кънязь Печенъжьскыи .. рече ему, ”выпусти ты свои мужь, а я свои, да ся борета“"

'The prince of the Pechenegs told him [Prince Volodimir], "Send your champion and I will send mine, so that they might fight each other" (122: 16-8).

Such discourse is usually introduced by a verb of speech, as in example (1), though direct discourse can also appear without a speech verb:

(2) И повель осьдьлати конь: “Атъ вижю кости его”.

And he ordered to saddle a horse: "I will see his bones" (39: 5)

Though direct discourse is prominent as an original tool of the narrator, it also appears quite frequently in quotes of biblical speakers or God (153 examples), e.g.:

(3) Ибо Господь рече: “Приходящаго къ мънъ не иждену вънъ”.

For God says: "I will not banish the one who comes to me" (62:24)

In addition to direct discourse, PVL has six instances of indirect discourse, which involves a change of deixis from speaker-oriented to reporter-oriented:

(4) ..повьдаша бо ему, яко хотять убити $\underline{\underline{\Lambda}}$

'He was told that [some people] want to kill him'

In addition to direct and indirect discourse, we also find deixis-neutral reported speech, i.e. reported speech that lacks deictic indication, either because the speech features third person pronouns and verbs that stay the same in direct and indirect discourse, or because deictic markers are absent:

(5) Повъдаша ему, яко утро хотять ся людие предати Печенъгомъ 'they told him that come morning the people want to surrender to the Pechenegs'. These three types of reported speech (direct, indirect and deixis-neutral discourse) can be introduced in two ways:

i. $\quad$ verb of speech +reported speech (682 total examples, of them 153 quote the Bible)

Рекоша Козаре, "Платите намъ дань" "The Khazars said, "Pay tribute to us"” 
ii. verb of speech + jako 'that' + reported speech (74 examples, of them 4 quote the Bible)

Се слышавъ Давыдъ и Ольгъ...начаста плакати ся, рекуща, яко “Сего не было въ родъ нашемь" 'Hearing this, David and Oleg... began to cry, saying that "this has never happened in our family".

Table 1: Distribution of reported speech types

\begin{tabular}{|l|l|l|l|}
\hline $\begin{array}{l}\text { Type of reported speech } \\
\text { Introduced by }\end{array}$ & $\begin{array}{l}\text { Direct discourse, } \\
\text { speaker-oriented } \\
\text { deixis present }\end{array}$ & $\begin{array}{l}\text { Deixis- } \\
\text { neutral } \\
\text { discourse }\end{array}$ & $\begin{array}{l}\text { Indirect discourse, } \\
\text { reporter-oriented } \\
\text { deixis present }\end{array}$ \\
\hline Verb of speech without jako & + & + & - \\
\hline Verb of speech + jako & + & + & + \\
\hline
\end{tabular}

3.1. Deixis-neutral discourse. Reported speech with neutral deixis is usually introduced with jako. These utterances can be interpreted as either direct or indirect discourse, since there are no formal means of classifying these utterances. Some indication of their status is often provided by the surrounding discourse.

Deixis-neutral discourse can be introduced without jako, though this is infrequent and usually happens with biblical quotes, or in dialogues where other instances of reported speech exhibit speaker-oriented deixis; by analogy, the deixis-neutral instances of reported speech read like direct discourse (6):

(6) на пятое льто ... призъва старъишину конюхомъ, река: “Къде есть конь мои, егоже бъхъ поставилъ кърмити и блюсти его?” Онъ же рече: “Умьрлъ есть”.

'In the fifth year [Oleg] summoned the head of the stables, saying: "where is my horse, which I have ordered to be fed and kept well?" He said, "[The horse] has died".

About a third of all examples of jako with reported speech are deixis-neutral, i.e. do not include a changeable person deixis ${ }^{6}$. Indication might be given by the context. In example (7), monks express their views on the suitability of one Iosif to succeed the head of the monastery, Feodosii; the utterance has no changeable deixis. ${ }^{7}$ Example (8) continues the conversation of the monks, who propose a different candidate; the deictic orientation of подъ рукою твоею "under your hand' testifies to its status as direct discourse:

(7) Братии же нелюбо бысть, глаголюще яко "Не сьдъ есть постриганъ” The brethren did not like this, saying that "He was not ordained here" (187:1-2) 
(8) И начаша братия просити Стефана деместьника, суща тъгда ученика Феодосиева, глаголюще, яко “Сьсь възраслъ есть подъ рукою твоею, и у тебе послужилъ есть;”. And the brethren started asking to have Stephan the Cantor, who was then a student of Feodosii, saying that "He has grown up here, under your hand, and served under you". $(187: 5-7)$

However, many instances of reported speech without changeable deixis cannot be classified with certainty as either direct or indirect discourse. The statistics for these constructions are given separately for direct, indirect, and deixis-neutral discourse (an example is counted as deixis-neutral even if there are indications of its probable status in the surrounding discourse). The conditions under which the deixis-neutral jako with reported speech appears are often identical to those of jako recitativum.

3.2. Treatment of reported speech variation in literature. Though reported speech constructions in Early Slavic attracted scholarly attention, functional motivations for the appearance of reported speech with jako are underexplored in previous studies. Voloshinov describes the Old Russian reported strategies as involving predominantly direct discourse: "Indirect discourse in Old Russian chronicles is extremely rare. Reported speech is incorporated everywhere as a compact, impermeable block with little or no individualization". This technique is described by Voloshinov as “authoritarian dogmatism” (Voloshinov 1929/1973: 120ff).

Direct discourse with and without jako were briefly contrasted by Lunde, who notes that direct speech without jako is slightly more salient and foregrounded than direct speech with jako (Lunde 2005: 49-80); jako recitativum is, in its turn, more foregrounded than indirect discourse (ibid., 17). Jako recitativum is more often discussed in the context of OCS (e.g. Večerka 1989, 2001). Jako recitativum is often treated in studies of OCS as an early form of indirect speech (Xaburgaev 1986; Matveeva-Isaeva 1958) or a strategy whereby reporting starts with indirect speech and switches to direct (Gamanovic 1991:251, as quoted in Collins 1996: 26). Collins (1996) disagrees with this treatment, convincingly showing that indirect discourse, i.e. reported speech involving a shift to reporter-oriented deixis, is attested in the earliest OCS writings. Collins argues that jako recitativum cannot be a form of indirect discourse, since this construction does not exhibit a shift of deixis. Since his primary interest is in indirect discourse, jako recitativum does not receive extensive treatment. Collins writes that "jako recitativum may 
be viewed as a result of a tendency to make textual relations explicit... [and] may be linked to syntactic pleonasms... and redundant conjunctions such as jako da" (Collins 1996:34). Collins further suggests that the jako + direct discourse construction may be a calque of Greek hoti or hos. (Similar views were advocated by Vaillant 1964, §258.)

In the Old Russian texts such as Povest' Vremennykh Let, both direct discourse, jako recitativum and, to a lesser extent, indirect discourse are attested. It is specifically for such original works that it becomes crucial to understand the differences between the types of reported speech. These differences serve narrators in the construction of narratives; for Old Russian, Lunde remarks that the variety and interplay of different forms allows the narrator to create vividness (enargeia) in a text. Lunde believes that "the variety of forms is reflected in a variety of pragmatic functions" (Lunde 2004:10).

The variation of reported speech forms is regularly associated with shifting from the narrator's to the speaker's point of view. These differences are usually considered in terms of direct versus indirect discourse: direct speech claims to convey the speech event as it occurred; it "imitates or presents the reported speech event from the perspective of the reported, whereas the indirect form analyzes or interprets the event from the perspective of the current reporting event... Among the more important contrasts [indirect and direct discourse] is the shifting back and forth between a narrator's and a character's point of view" (Lucy 1993:18). Indirect discourse is statistically insignificant in the PVL, and shifting from direct to indirect discourse is not an important feature of the PVL narrative structuring. What is important for indicating viewpoint is the shift from plain direct discourse to jako recitativum.

\section{$\underline{4 .}$ Direct discourse introduced by jako}

An examination of the Primary Chronicle yielded two main functions for the employment of jako with direct discourse. The first function concerns evidentiality /epistemic stance: the narrator/reporter distances himself from the content of the utterance he is reporting (for example, the chronicler records a point of view which he considers erroneous). The second function ranks speakers in the order of importance. Some speakers are central to the narrative and are mentioned by name or by personal pronouns. Other speakers are not significant enough to be mentioned by name, and yet their speech is important enough to be reported (for example, envoys are speaking to the prince). The discourse of such secondary speakers is often marked by jako. The two 
strategies need not be considered as wholly separate. The speech of secondary characters, especially those in opposition to the main protagonist, is often marked by the narrator's negative or distancing attitude.

4.1 Evidentiality/Distancing.Reported speech not only presents information, but can also indicate the speaker's evaluative stance towards the knowledge and its source (cf. Grenoble 1998:111). This stance is usually referred to as 'evidentiality', a term that has warranted a lively discussion (e.g. Chafe 1986, Chafe and Nichols 1986, Willett 1988, Ifantidou 2001, Aikhenvald 2003, 2004). The literature has produced various definitions depending largely on the linguistic data used in the studies. Nichols and Chafe 1986 define evidentiality as linguistic encoding of the speakers' attitude towards knowledge or sources of knowledge. For Aikhenvald (2004), who conducts a thorough cross-linguistic study, evidentiality is strictly a grammatical category; applicable to languages that obligatorily state the existence and nature of evidence for information (Aikhenvald calls such obligatory marking systemic). Further confounding the issue, the category of evidentiality can pertain to a) the source of information (eyewitness report; hearsay; inductive reasoning, etc.) or b) the epistemic stance towards that knowledge (e.g. speaker marks knowledge as false or unreliable). In some languages, evidentiality can apply to either to the source of knowledge or to the epistemic stance towards it; other languages mix the two. Neither Old nor Modern Russian has a morphologically encoded, systemic evidentiality; however, lexicalized evidentials, i.e. linguistic devices marking source of information or the speakers' attitude towards it, do exist both in Modern Russian (cf. Grenoble 1998: 133-5) and Old Russian reported speech. Specifically jako, when it introduces reported speech in the PVL, signals the narrator's distancing attitude toward the content of discourse and/or towards its source. Authorial distancing is expressed when reporting political intrigue, pagan discourse, and erroneous opinions.

4.1.1 Political intrigue. A fair number of examples with this construction appear in contexts involving political intrigue, especially deception, libel, and enticement to murder. In example (9), Oleg is enraged when the two Vikings named Askold and Dir pronounce themselves to be of princely descent. Oleg deceives the Vikings into believing him to be a harmless merchant: 
(9) И приступль подъ Угърьское, похоронивъ воя своя, и посъла къ Асколду и Диру, глаголя, яко "Гостие есмы, идемъ въ Грькы отъ Ольга и отъ Игоря къняжича; да придъта къ роду своему къ намъ”.

He advanced upon the Ugor land, having hid his warriors, and sent to Askold and Dir, saying that "we are merchants, going to Byzantium from Prince Oleg and Prince Igor; come to your kinsmen, to us". (23:10)

Another example of political deception is (10), where the princess Olga is set on avenging the murder of her husband by the tribe of Derevlyane. When envoys come from the tribe, Princess Olga tells them that she has already avenged her husband three times and no longer desires revenge. The gullible Derevlyane fall into her trap and are slain:

(10) Рече же имъ Ольга, яко “Азъ уже мьстила мужа своего, кьгда придоша Кыеву, и въторое, и третьее, къгда творяхутъ тризну мужю моему; а уже не хощю мьщати. Olga said to them, that "I have already avenged my husband, when they came to Kiev, and a second and third time when they made a wake for my husband; and I do not want revenge any more".

By using jako with Olga's speech, the narrator is indicating that the reader should be aware of Olga's intention to trick the Derevlyane: her speech should not be taken at face value.

Libel is another frequent context of political intrigue in which jako recitativum appears. In example (5), Prince Svyatoslav entices Vsevolod to take up arms against his brother Izyaslav by presenting Izyaslav as conspiring against Vsevolod and himself:

(11) Святославъ же бъ начало выгънанию братьню, желая большая власти; Вьсеволода бо прельсти, глаголя, яко "Изяславь сватаеть ся съ Вьсеславьмь, мысля на наю" Svyatoslav was the source of his brother's exile, wishing for more power; he enticed Vsevolod, saying that "Izyaslav is conspiring with Vseslav, thinking to kill us".

Assassination of kinsmen is frequently a feature of princely intrigue; utterances enticing murder or proclaiming murderous intent are also presented with jako+direct discourse, as in (12), where Blud reports to Prince Volodimir that his rival Yaropolk is now in his power and ready to be dispatched:

(12) И посъла Блудъ къ Володимиру сице глаголя, яко “Събысть ся мысль твоя, яко приведу Яропълка къ тебъ, и пристрои убити и" 
And Blud sent to Volodimir saying thus, that "Your thought came to pass, that I will lead Yaropolk to you, and you will arrange to have him killed".

By choosing jako recitativum, the chronicler marks his negative attitude towards the content of the utterance which reports evil intent. His attitude towards the speaker is often similarly disparaging, as in (13), where Prince Svyatopolk is called оканьныл зъльли 'accursed evil one':

(13) Святопълкъ же оканьныи зълыи уби Святослава... И нача помышляти, яко “Избию вьсю братию свою, и прииму власть Русьскую единъ”.

Svyatopolk, the accursed evil one, killed Svyatoslav. And he started thinking that "I will kill all my brothers, and will alone take on the Rus'ian rule". (139: 18)

The narrator's negative attitude towards the speakers is illustrated also by example (14), where henchmen are sent by Svyatopolk to murder Gleb. Having accomplished their vile deed, these оканьнии 'accursed ones' return to report:

(14) Оканьнии же възвратиша ся въспять...Онъмъ же пришьдъшемъ и повьдашавъшимъ Святопълку, яко “Сътворихомъ повельное тобою”.

The accursed ones then returned... Having returned, they reported to Svyatopolk that "We have carried out your order" (137: 3).

4.1.2 Distancing from non-Christian utterances. Authorial distance is also prominent when reporting pagan or non-Christian content. Speech by the pagan magicians, or volkhvy, is represented in PVL on a number of occasions. In the famous episode of Yan and the magicians (year 1071), the narrator distances himself from the blasphemous utterances of the two pagans by prefacing their speech with jako:

(15) Бывъши бо единою скудости въ Ростовьстьи области, въстаста дъва вълхва отъ Ярославля, глаголюща, яко “ВЪ съвђмы, къто обилие дьржить”.

There was once hunger in Rostov district; two magicians arose from Yaroslavl', saying that "we two know who is responsible for the poor harvest" (175:7)

The author distances himself from the words of pagans, and the religious utterances of nonChristians, such as the Jews and the Muslim Bulgars in the story of the Christening of Rus':

(16) Придоша Българе въры Бохъмичи, глаголюще, яко “ты кънязь еси мудръ съмысльнъ, не въси закона. Да въруи въ законъ нашь, и поклони ся Бохъмиту”. 
There came Bulgars of the Mohammedan faith, saying that "you prince are wise and smart, but you do not know the law. Believe in our law, and worship Muhammad" (84: 18)

The Devil's speech (17) receives a similar treatment:

(17) Тако бо тъщаше ся погубити родъ хрьстьяньскыи, нъ прогонимъ бяше крьстъмь чьстьнымь въ инъхъ странахъ; сьде же мьняше ся оканьныи, яко “Сьде ми есть жилище, сьде бо не суть учили апостоли, ни пророци прорекли”

Thus he tried to destroy the Christian kin, but he was banished by the true cross in other lands; here the accursed one thought to himself that "Here there is a habitation for me, since here the apostles did not teach, nor the prophets prophesy" (83:15)

4.1.3 Erroneous content. In addition to political deception and pagan views, jako introduces utterances whose content is presented as erroneous or disagreeable. In (18), the chronicler claims that the views of other historians are wrong, and contrasts those views to his own:

(18) Ини же, не въдуще, рекоша, яко Кыи есть перевозьникъ былъ. Аще бо бы перевозьникъ Кыи, то не бы ходиль къ Цьсарюграду, нъ сь Кыи къняжаше въ роду своемь.

Others, not knowing, said that Kyi was a ferryman. If he was a ferryman, he would not have gone to Constantinople, but this Kyi was a prince of his kinsmen. (9.22)

The same function is used when the author disagrees with opinions expressed in the utterance. In example (19), jako precedes the discourse suggesting that no languages but Greek, Latin, and Hebrew should have their own alphabet:

(19) Нъции же начаша хулити Словъньскыя кънигы, глаголюще, яко “Не достоить ни которому же языку имъти букъвъ своихъ, развъ Евръи и Грькъ и Латинъ..”. Се же слышавъ папежь Римьскыи, похули тъхъ, иже ръпъщуть на кънигы Словђньскыя, река: “Да ся испълнить кънижьное слово, яко въсхвалять Бога вьси языци”.

Some then started to condemn Slavic books, saying that "No nation is worthy of having its own script, except the Jews, the Greeks and the Romans..." Hearing this, the Pope of Rome condemned those who speak against Slavic books, saying "Let the word of the Bible come true, that all tongues should worship God". (27:9). 
Naturally, the narrator of the PVL disagrees with abuse of the Slavic letters, and supports the pope's opinion on the matter. Jako marks the fallacious opinion, but in contrast, the narrator does not use jako with the Pope's speech.

Occasionally this strategy may also be found with indirect discourse, as in (20):

(20) Да никътоже дьрзнеть рещи, яко ненавидими Богьмь есмы!

Let no one dare say that we are hated by God!

4.1.4. Irrealis. Another jako+direct discourse context involves utterances whose content describes future events. The speaker, at the moment of speech, presumes that the events he is talking about will indeed come to pass. On the other hand, the narrator, at his point in time, knows that these events will not occur. To indicate this discrepancy he precedes the direct discourse of the speaker with jako, as in (21):

(21) Изяславъ же иде въ Ляхы съ имъниемь мъногымь и съ женою, уповая богатьствъмь мъногымь, глаголя, яко “Симь налъзу вои”.

Izyaslav goes to the Poles with much treasure and with his wife, trusting in his wealth, saying that "With this I will recruit warriors". (183: 3)

In this example, Izyaslav goes to Poland, planning to recruit an army with his gold. The narrator knows that his plan will fail: in the following lines, we read that the Poles rob Izyaslav of his wealth and banish him from their lands.

4.1.5. Embedded speech. Finally, jako+ direct discourse is also used with evidential rather than epistemic pragmatics when a speaker's utterance in turn reports the speech of another. This direct discourse, already embedded in direct discourse, is always introduced by jako:

(22) Се же хощю съказати, ... яже ськаза ми Гурята Роговичь Новъгородьць, глаголя сице, яко "Посълахъ отрока своего въ Печеру, люди, иже суть дань дающе Новугороду"

I want to say this, which Gurata Rogovich from Novgorod told me, saying this that "I sent my servant to Pechera, who are a people giving tribute to Novgorod"

There is PVL-internal evidence that the jako-introduced embedded direct discourse does not convey verbatim the speech it attempts to quote (a number of scholars have argued that direct discourse does not convey the original message verbatim, e.g. Sternberg 1982, Tannen 1989, 
Collins 2001:49-58). In example (23), David son of Igor slanders Vasilko, telling Svyatopolk that Vasilko plans to kill them both and is conspiring with Prince Volodimir:

(23) Давыдъ же, имъ въру льживымъ словесемъ, нача мълвити на Василька, глаголя сице: “Къто есть убиль брата твоего Яропълка, а нынъ мыслить на тя и на мя, и съложиль ся есть сь Володимирьмь? Да промышляи о своеи головь”.

David, believing the lying words, started slandering Vasilko, saying this: "Who is it that had killed your brother Jaropolk, and now plans to kill you and me, and joined with Volodimir? Take care of your head". (257: 17-21)

In (24), in an attempt to explain his criminal behavior towards Vasilko, Svyatopolk tells his noblemen about the slander: "David told me that Vasilko is plotting with Volodimir, planning to kill you and occupy your cities". In (25) this scenario repeats again, with some differences:

(24) Наутрия же Святопълкъ съзъва боляре и Кыяне, и повъда имъ, еже бъ ему повьдаль Давыдъ, яко “Брата ти убилъ, а на тя съвъщаль съ Володимиръмь, хочеть тя убити и грады твоя заяти".

On the morning Svyatopolk called the noblemen and Kievans, and told them that which David told him, that "[he] killed your brother, and took council against you with Volodimir, [he] wants to kill you and occupy your cities". (259: 25)

(25) И рече Святопълкъ, “Повъдалъ ми Давыдъ Игоревичь яко Василько брата ти убиль, Яропьлка, и тебе хощеть убити и заяти волость твою.

And Svyatopolk said, "David son of Igor told me that "Vasilko killed your brother, Jaropolk, and wants to kill you as well and to occupy your province". (263:6)

Note the differences in wording between those three versions, such as the addition of Vasilko's territorial ambitions in (24) and (25).

The examples above support the claim that reported speech, even when presented as direct discourse, does not always faithfully record the direct discourse of the protagonists (Fludernik 1993:17, Sternberg 1982). Similarly, Lunde argues that in "fictional or quasi-fictional texts, direct speech cannot have the intention of faithfully reproducing the words of the quote. Rather than render verbatim some previously spoken utterances, direct speech is typically introduced with the aim of contouring a clearer view of the speaker" (Lunde 2004, 57). The issue of faithfulness of representation becomes more complex in our case, since the original speech is reproduced by a chain of reporters. The direct discourse attributed to the character in (23) is not a 
verbatim report, if the original report had indeed taken place. Every time we read reported speech in the chronicle we should recall that the chronicler hears this from an eyewitness, i.e. there is at least one additional intermediary between the actual speaker and the narrator. The eyewitness may or may not be able to render the original utterance verbatim, and may not even be concerned with having a total recall of all utterances he is relaying to the chronicler. The chronicler, in turn, may or may not record verbatim the report received from an eyewitness ${ }^{8}$. The issue of faithfulness might be moot, since the report might never have occurred in reality, but might be completely a creation of the narrator. However, this report, once put into the mouth of a protagonist, has a text-internal existence and can be reported on, text-internally, by other protagonists (whose utterances are controlled by the narrator according to either of the scenarios described above). In (24) and (25), Svyatopolk reports on the content of David's speech to him while omitting some details (e.g. that Vasilko threatens David as well as Svyatopolk), and adding others (Vasilko's territorial ambitions). The interplay between text-internal considerations (Svyatopolk may want to present the threat of Vasilko as larger than originally indicated by David) and text-external, narrator-driven considerations, is complex and cannot be established with certainty from the data at hand. However, text-internally the usage of jako (24) and (25) as opposed to its lack in (23) signals viewpoint focus and attributes originality to David's utterance; Svyatopolk's retellings in (24) and (25) are presented as less reliable, distanced reports.

Table 2 summarizes the distancing contexts of jako+reported speech and presents data on frequency of the three types of reported speech in those contexts.

Table 2: Distancing contexts

\begin{tabular}{|l|r|r|r|r|r|}
\hline Context & $\begin{array}{l}\text { No.of } \\
\text { examples }\end{array}$ & \% of total & $\begin{array}{l}\text { Direct } \\
\text { discourse }\end{array}$ & $\begin{array}{l}\text { Deixis-neutral } \\
\text { discourse }\end{array}$ & $\begin{array}{l}\text { Indirect } \\
\text { discourse }\end{array}$ \\
\hline $\begin{array}{l}\text { Deception, libel, enticement to } \\
\text { murder in a political context }\end{array}$ & 17 & $30.3 \%$ & 15 & 2 & 0 \\
\hline Pagan or non-Christian content & 15 & $26.8 \%$ & 9 & 4 & 2 \\
\hline $\begin{array}{l}\text { Author presents information as } \\
\text { erroneous or disagrees with opinion }\end{array}$ & 8 & $14.3 \%$ & 3 & 4 & \\
\hline $\begin{array}{l}\text { Content of direct speech does not } \\
\text { come to pass }\end{array}$ & 7 & $12.5 \%$ & 6 & 1 & 0 \\
\hline Speech embedded in speech & 9 & $16.1 \%$ & 6 & 1 & 2 \\
\hline Total & 56 & $100.00 \%$ & 39 & 12 & 5 \\
\hline
\end{tabular}


As discussed above, evidential values of jako are not systemic in Old Russian, i.e. its marking is not obligatory. The usage of jako with direct discourse is not obligatory even in the distancing contexts discussed above. I found a few examples of direct discourse without jako with utterances expressing political deception and pagan views; for example in (26), Volodimir offers to conspire with Blud against Yaropolk. Despite the apparent authorial disagreement with their actions, the exchange between Volodimir and Blud is delivered through direct discourse without jako:

(26) Володимирь: же посъла къ Блуду, воеводъ Яропълчю, съ льстию, глаголя: “Поприяи ми; аще убию брата своего, имъти тя начьну въ отьца мъсто... И рече Блудъ къ посъланымъ Володимиръмь: “Азъ буду тобъ въ сьрдьце и въ приязньство”. О зълая льсть человђчьска!

Volodimir then sent to Blud, Yaropolk's general, with treachery, saying: "Assist me; if I kill my brother, I will respect you as a father... And Blud said to the envoys of Volodimir: I will be with you in heart and in friendship". Oh evil treachery of mankind!

Direct discourse without jako might have been chosen due to a different set of considerations, namely ranking of speakers in the order of importance, which will be discussed in detail in section 5. Even though the appearance of jako is not a systemic indicator of evidentiality, it has distancing semantics when preceding direct discourse, and may be used by the narrator to indicate his distancing and/or negative epistemic stance towards the content of an utterance.

\section{$\underline{\text { 5. Ranking of speakers with jako+reported speech }}$}

The conjunction jako often precedes reported speech of secondary protagonists. These characters are ranked as unimportant to the narrative, while the content of their speech is presented as important. A clear-cut case of such ranking appears in utterances where the speakers (usually envoys or scouts) are not stated due to their lack of importance to the narrative. Such is example (27), where tidings are conveyed, presumably, through envoys: 
(27) И приде Мьстиславу въсть, яко “Посьлаль ти отьць Вячеслава брата сь Половьци”. And tidings came to Mstislav that "Your father sent you your brother Vyacheslav with the Polovcy".

Similarly in (28), reported speech without changeable deixis:

(28) И повьдаша Ользъ, яко Деревляне придоша.

And [they] told Olga that Derevlyane had arrived.

In some examples the word посълании 'envoys' appears overtly, though the identities of these men are irrelevant to the narrative. The speech of these secondary protagonists is again preceded by jako:

(29) РЪша же посълании, яко “Придохомъ къ нему, и въдахомъ дары, и не позьръ на ня, и повель сьхранити".

The envoys said that "We came to him, and gave the gifts, and he did not look upon them and ordered to take them away"

Unnamed protagonists are often presented as secondary in relation to named ones that occupy the center of narration. In the story of Yan and the Volkhvy, Yan helps the citizens of Belozero to get rid of two pagan magicians. In a dialogue between the two, jako precedes the discourse of the citizens:

(30) Въ сеже время приключи ся прити отъ Святослава дань емлющю Яневи, сыну Вышатину; повъдаша ему Бълозерьци, яко дъва кудесьника избила мъногы жены по Вълзъ и по Шекъснь, и пришьла еста сьмо.

At that time it happened that Yan, son of Vyshata, was coming from Svyatoslav collecting tribute. The citizens of Belozero told him that two magicians killed many women along the Volga and Sheksna rivers, and came here.

In the same story, jako also precedes the speech of the two magicians as they converse with Yan (this is also due to the pagan views as discussed in section 4.1.2). Yan's speech is never conveyed though the jako construction:

(31) И рече има: “Чьто ради погубиста толико человъкъ?” Онъма же рекъшема, яко “Ти дьржать обилие; да аще истребивђ и избиевђ сихь, будеть гобино".

He said to them "What for did you kill so many people?" They said, that "they are responsible for the poor harvest; and if we kill and destroy those, there will be abundance" (176: 17-21) 
The ranking function of jako is often combined with other contexts such as political intrigue and embedded speech. In the Blinding of Vasilko, some unnamed men libelously claim that Vasilko of Terebovl' is plotting against Prince Svyatopolk. David believes these sources and convinces Svyatopolk to maim their kinsman Vasilko:

(32) И вълЂзе сотона въ сьрдьце нъкоторымъ мужемъ, и почаша глаголати къ Давыдови Игоревичю, рекуще сице, яко “Володимиръ съложиль ся есть съ Василькъмь на Святопълка и на тя".

And the devil entered the hearts of some men, and they started speaking to David son of Igor, saying this, that "Volodimir conspires with Vasilko against Svyatopolk and yourself".

When Prince Volodimir learns about the blinding of Vasilko, he says that such a crime was never before committed in Rus' even in the times of his ancestors (ex. 33, direct discourse without jako). Volodimir summons the sons of Svyatoslav, David and Oleg (introduced for the first time in that passage), and relays the news to them. Their reaction mirrors Volodimir's: such a crime has never been committed in the family. However, their direct discourse is preceded by jako, marking the status of Svyatoslav's sons as secondary and of Volodimir as the main character:

(33) Володимиръ же слышавъ, яко ятъ есть Василько и сльпленъ, ужасе ся, и въсплака ся вельми, и рече: “Сего не бывало есть въ Русьскои земли ни при дъдъхъ нашихъ, ни при отьцихъ нашихъ, сяко го зъла".

Volodimir then hearing that Vasilko was taken and blinded, was horrified and cried much, and said: "This never occurred in the Russian land, not in the times of our grandfathers, nor in the times of our fathers, such evil" (262: 7-10)

(34) Се слышавъ Давыдъ и Ольгъ, печальна быста вельми и начаста плакати ся, рекуща,: яко “Сего не было въ родъ нашемь”.

Hearing this, David and Oleg were very sad and began mourning, saying that "This never occurred in our family" (262:19-20)

Table 3 summarizes the distribution of jako+ reported speech in contexts where the speakers are ranked unimportant or secondary:

Table 3. Ranking of speakers with jako + reported speech 


\begin{tabular}{|l|r|r|r|l|l|}
\hline Context & \multicolumn{1}{|l|}{$\begin{array}{l}\text { Total } \\
\text { examples }\end{array}$} & \% of total & $\begin{array}{l}\text { Direct } \\
\text { discourse }\end{array}$ & $\begin{array}{l}\text { Deixis-neutral } \\
\text { reported speech }\end{array}$ & $\begin{array}{l}\text { Indirect } \\
\text { discourse }\end{array}$ \\
\hline Ellipsis of speakers & 8 & $38.10 \%$ & 1 & 5 & 2 \\
\hline Unnamed speakers & 10 & $47.62 \%$ & 6 & 4 & 0 \\
\hline $\begin{array}{l}\text { Named speakers that are } \\
\text { contrasted to main characters }\end{array}$ & 3 & $14.29 \%$ & 3 & 0 & 0 \\
\hline Total & 21 & & 10 & 9 & 2 \\
\hline Total \% & & $100.00 \%$ & $47.62 \%$ & $42.86 \%$ & $9.52 \%$ \\
\hline
\end{tabular}

6.0 Jako+reported speech in non-distancing contexts

6.1. Biblical quotes. There are seven examples of jako+direct discourse being introduced in biblical contexts. Of those, four are directly quoting the Bible, e.g. (35), which quotes Matthew 15, 10:

(35) Рече бо Господь яко радость бываеть на небеси о единомь грђшьницъ кающемь ся. The Lord said that "there is joy in heaven over one sinner that repenteth" (120:2) In addition, there are three examples referring to Biblical content without providing a direct quote, as in (36), from a sermon of Feodosii summarizing the laws of Lent. Those speeches are delivered by major church figures.

(36) Глаголашеть бо сице, яко “Богъ даль есть намъ 40 днии сию на очищение души.

He said thus, that "God gave us these 40 days to cleanse our souls". (184:22-23) There are two possible motivations for usage of jako: first, that this is yet another distancing context that has to do with evidential semantics and distancing from quoted material; second, that this usage is stylistic, mimicking the functionally neutral (or at least non-distancing) use of jako in OCS texts. The first option seems less likely: Biblical quotes and contexts are frequent in the PVL, but only a few of them use jako to introduce reported speech ${ }^{9}$. In addition, the distancing contexts discussed above all involve a negative /distancing attitude towards the content of reported speech - this is not so with biblical quotes. However, there are not enough examples of this context to make a solid judgment.

Table 4 summarizes four major contexts for appearance of jako with reported speech: 1) the author seeks to distance himself from the content of the reported speech (for the breakdown of those contexts see Table 2); 2) jako initiates reported speech of secondary agents; 3) jako introduces biblical quotes or speech of iconic church figures - this usage is most likely modeled 
after OCS texts; 4) contexts which appear not to carry an additional semantic component, and those that could not be categorized otherwise with any degree of certainty.

Total number of jako+reported speech constructions counted is 74. Of them, 14 examples were classified as belonging simultaneously to two subtypes of distancing (e.g. deception and ranking of speakers/ unnamed). These examples were counted twice. In addition, a single example exists in two variants, of Direct and Indirect discourse, in the two recensions of the PVL. This example was also counted twice, bringing the total number to 89 .

Table 4. Contexts for jako with reported speech constructions

\begin{tabular}{|c|c|c|c|c|c|}
\hline & \multirow{2}{*}{$\begin{array}{l}\text { Total } \\
\text { examples }\end{array}$} & \multirow{2}{*}{$\begin{array}{l}\text { Percentage of } \\
\text { total } \\
\text { examples }\end{array}$} & \multicolumn{3}{|c|}{ Type of reported speech } \\
\hline & & & $\begin{array}{l}\text { Direct } \\
\text { discourse }\end{array}$ & $\begin{array}{l}\text { Deixis- } \\
\text { neutral } \\
\text { discourse }\end{array}$ & $\begin{array}{l}\text { Indirect } \\
\text { discourse }\end{array}$ \\
\hline $\begin{array}{l}\text { Distancing from } \\
\text { content (see also } \\
\text { Table 2) }\end{array}$ & 56 & $62.9 \%$ & 39 & 12 & 5 \\
\hline $\begin{array}{l}\text { Speech of } \\
\text { secondary agents } \\
\text { (see also Table } 3 \text { ) }\end{array}$ & 21 & $23.6 \%$ & 10 & 9 & 2 \\
\hline $\begin{array}{l}\text { Biblical context or } \\
\text { quote }\end{array}$ & 7 & $7.9 \%$ & 4 & 3 & 0 \\
\hline $\begin{array}{l}\text { Neutral / } \\
\text { uncategorized }\end{array}$ & 5 & $5.6 \%$ & 3 & 2 & 0 \\
\hline Total & 89 & $100 \%$ & 56 & 26 & 7 \\
\hline
\end{tabular}

Out of six examples of indirect reported speech, four appeared in distancing contexts, one in a ranking context, and one in both ranking and distancing contexts. Though there are not enough examples to judge with certainty, this data shows indirect discourse to behave similarly to jako recitativum in this text.

\section{Conclusions}

Jako recitativum is much less frequent in the PVL than direct discourse without jako; however, it can be productively contrasted to it in function. Direct discourse without jako is 
significantly more frequent in the PVL than any other kind of reported speech; it can be taken to mean that the narrator agrees with the speaker or at least does not disagree with him/her. When jako is used, it serves to contrast two viewpoints, that of the speaker and that of the narrator. By differentiating the perspective of the narrator from that of the speaker, the jako construction allows the narrator to offer epistemic commentary on the truth value, as well as the moral value, of reported speech. Thus, the narrator is not always a covert presence in the chronicle; his involvement with the information he conveys is more complex than was previously realized.

Three factors, central for previous analyses of Old Russian reported speech, appear to be secondary to this distribution, namely the question of bookishness, drama versus veracity in the choice of reported speech type, and, in general, opposition of direct and indirect discourse.

Bookishness. Use of subordinating jako in all its functions is said by some scholars of Old Russian to be ‘bookish' (Borkovskii and Kuznetsov 1963: 491, Lomtev 1956 507-8) as opposed to чъmo 'that', a conjunction with similar functions. The implicit evaluation of a construction as bookish is that it does not have a pragmatic meaning other than indicating that a text belongs to a certain written register. In fact, it was shown above that jako does have a meaning that is internal to the text, a function that is not just a reflex of its status as a construct of the written language.

Though the exact diachronic development of jako between the time PVL was written and the present is unknown to me, traces of its form and function are preserved in Modern Russian jakoby. According to Rakhilina (1996: 299-304), Modern Russian jakoby is a conjunction which introduces the speech of the other, and offers an epistemic commentary on this speech: $O H$ говорил, что его яко бы окружают враги 'he said that he is jakoby surrounded by enemies' (the speaker does not believe this statement). Rakhilina shows that the other's utterance is judged by the speaker as "false" in terms of its truth value and therefore the speaker's attitude towards the utterance is negative. It is hard to say without further investigations whether this evolution means jako did exist in speech, or that it developed epistemic semantics solely through written language. However, the data suggests that jako existed in Old Russian not just as a bookish, frozen construct, but as an entity a well-defined pragmatic function and history.

Drama versus veracity. Direct discourse, purportedly aiming to reproduce a speech event as it occurred, is often seen as vivid and immediate, and thus authoritative (for discussion, see Lucy 1993:18). However, a preference for direct discourse in a chronicle is unusual; in 
comparison, medieval French chroniclers prefer indirect to direct discourse, even though the historical texts are often composed by authors who directly witnessed the events. According to Sophie Marnette (1999, and 2005: 198-9), the preference for indirect discourse in the French chronicles has to do with projected truthfulness of representation: the chroniclers present themselves as credible witnesses by recognizing the "finiteness of their own memory", so as not to give an "impression that they could really remember everything that was said". This is congruent with our perception of historical record, which emphasizes objectivity, or truthfulness, by avoiding speech representation unless it can be authenticated from recordings. May (1997) demonstrates that direct discourse of PVL is often replaced in later retellings (e.g. Vernadsky) and translations (such as Cross) by third-person indirect speech ${ }^{10}$. As modern readers, we tend to perceive indirect speech as more "historical" and direct speech as more "dramatic". Rendering historical events as they happened seems to have been important to our chronicler ${ }^{11}$; his preference for direct discourse might have had to do with what he perceived as faithful reporting. His usage of jako recitativum to indicate epistemic stance further supports the importance of veracity to our narrator, even though he does not use indirect discourse to pursue his goals.

Indirect vs. Direct Discourse. Despite the fact that both direct and indirect discourse was represented in the Early East Slavic writings, indirect discourse as we know it seems to be far too infrequent in PVL to be successfully contrasted in function to direct discourse (even if we include examples of reported speech with jako cum infinitivum). Paucity of indirect discourse may be specific to PVL, or it may be symptomatic of all original East Slavic writings (this awaits further investigation). It is possible, in fact, that indirect discourse is not important to the PVL. It is conceivable that the need to contrast direct to indirect discourse is due to our modern understanding of reported speech and is not motivated by the usage of the PVL. It is important to note that the PVL narrator exploits, for his narrative needs, the existence of variation in types of reported speech; the exact form of these types matters less.

\section{References}

Aikhenvald, Alexandra Y. (ed and introd )., R. M. W. Dixon, and Brian D. Joseph, eds. 2003. Studies in evidentiality. Typological Studies in Language, 54. Amsterdam: Benjamins, 2003.

Aikhenvald, Alexandra. 2004. Evidentiality. Oxford: Oxford University Press. 
Birnbaum, David and Donald Ostrowski, eds. The e-PVL. http://clover.slavic.pitt.edu/pvl/ .

Borkovskii, V. I, and Kuznetsov P. S. 1963. Istoricheskaia grammatika russkogo yazyka. Moskva: Izdatel'stvo akademii nauk SSSR.

Chafe, Wallace. 1994. Discourse, consciousness, and time: The flow and displacement of consciousness experience in speaking and writing. Chicago: $\mathrm{U}$ of Chicago $\mathrm{P}$.

- 1986. Evidentiality in English conversation and academic writing. In Evidentiality: The linguistic coding of epistemology, eds. Wallace Chafe, Johanna Nichols, 261-272. Norwood, NJ.

1982. Integration and involvement in speaking, writing, and oral literature. In Spoken and written language: Exploring orality and literacy, ed. Tannen, Deborah (ed.,\& introd.), 35-53. Norwood, NJ.

Chafe, Wallace, and Johanna Nichols, eds. 1986. Evidentiality: The linguistic coding of epistemology. Advances in Discourse Processes, 20. Norwood, NJ.

Collins, Daniel E. 1996. The pragmatics of indirect speech in Old Church Slavonic and other early Slavic writings. In Studies in South Slavic and Balkan Linguistics (=Studies in Slavic and General Linguistics), vol. 23: 21-86.

- 2001. Reanimated voices: Speech reporting in a historical-pragmatic perspective. Pragmatics \& beyond: New series, 85. Amsterdam, Netherlands: Benjamins, 2000.

Coulmas, Florian. 1986. Reported speech: Some general issues. In Direct and indirect speech, ed. Florian Coulmas, 1-28. Berlin: Mouton de Gruyter.

Coulmas, Florian (ed )., ed. 1986. Direct and indirect speech. Trends in Linguistics: Studies \& Monographs, 31. Berlin: Mouton de Gruyter.

Fludernik, Monika. 1993. The fictions of language and the languages of fiction: The linguistic representation of speech and consciousness. London: Routledge, 1993.

Gorshkov, A.I. 1963. Staroslavianskii yazyk. Moskva: Vysshaia Shkola.

Grenoble, Lenore. 1998. Deixis and information packaging in Russian discourse. Amsterdam: John Benjamins. 
Ifantidou, Elly. 2001. Evidentials and relevance. Pragmatics \& beyond: New series, 86 . Amsterdam, Netherlands: Benjamins, 2001.

Leech, Geoffrey N., and Michael H. Short. 1982. Style in fiction. Mervyn Peake Review 15, (Fall): 30-35.

Lixachev, D.S. 1945. Novgorodskaia letopis' XIII-XIV vekov. Istoriia russkoi literatury v 10 tomakh. Tom II. Chast' 1: Literatura 1220x-1580x godov. Moskva: Akademia Nauk SSSR.

Lomtev, T.P. 1956. Ocherki po istoricheskomu sintaksisu russkogo yazyka. Moskva: Izdatel'stvo Moskovskogo universiteta.

Lucy John, A. 1993. Reflexive language and the human disciplines. In Reflexive language: Reported speech and metapragmatics., ed. John A. Lucy, 9-32. Cambridge: Cambridge UP.

Lunde, Ingunn. 2005. Speech-reporting strategies in 'dramatic preaching': With examples from East Slavic festal sermons. In Speculum sermonis: Interdisciplinary reflections on the medieval sermon, eds. Georgiana Donavin, Cary J. Nederman, and Richard Utz, 273-291. Turnhout, Belgium: Brepols.

.2004. Rhetorical enargeia and linguistic pragmatics: On speech-reporting strategies in East Slavic medieval hagiography and homiletics. Journal of Historical Pragmatics 5 (1): 49-80.

Marnette, Sophie. 2005. Speech and thought presentation in French: Concepts and strategies. Pragmatics \& beyond: New series, 133. Amsterdam, Netherlands: John Benjamins. 1999. Narrateur et point de vue dans les chroniques médiévales: Une approche linguistique. In The medieval chronicle, ed. Erik Kooper, 174-190. Amsterdam, Netherlands: Rodopi.

May, Rachel. 1997. The power of speech: Dialogue as history in the Russian Primary Chronicle. In Dialogue and critical discourse: Language, culture, critical theory., ed. Michael Macovski, 47-64. Oxford, England: Oxford UP .

Matveeva-Isaeva, L.V. 1958. Lekcii po staroslavianskomu yazyku. Leningrad.

Ostrowski, Donald (ed and introd), David J. Birnbaum, Horace G. Lunt, and Omeljan Pritsak, eds. 2003. The povest' vremennykh let: An interlinear collation and paradosis. Harvard Library of Early Ukrainian Literature: Texts, 10. Cambridge, MA: Harvard Ukrainian Research Institute, 2003. 
Rakhilina Ekaterina, V. 1996. Jakoby comme procédé de médiatisation en russe. In L'enonciation médiatisée., ed. Zlatka Guentchéva, 299-304. Louvain, Belgium: Peeters.

Sternberg, Meir. 1982. Proteus in quotation-land: Mimesis and the forms of reported discourse. Poetics Today 3, (2) (Spring): 107-156.

Tannen, Deborah. 1989. 'I take out the rock - dok!': How Greek women tell about being molested (and create involvement). Anthropological Linguistics 25.3 (Fall): 359-374.

Vaillant, André. 1964. Manuel du vieux slave. (Institut d'Etudes slaves. Collection de manuels, 6). Vol.1: Grammaire. Paris.

Večerka, Radoslav. 1984. Staroslověnština. Praha.

— 2001. Tzv. "jako recitativum" v staroslověnštině. In Cyrillo-Methodiana in honorem Aemiliae Bláhová et Venceslai Konzal. Praha : Slovanský ústav-Euroslavica.

Voloshinov, V. N. 1929/1973. Marxism and the Philosophy of Language. Ladislav Matejka and I. R. Titunik (trans.). New York and London: Seminar Press.

Willett, Thomas. 1988. A cross-linguistic survey of the grammaticization of evidentiality. Studies in Language: International Journal Sponsored by the Foundation 'Foundations of Language' 12, (1): 51-97.

Xaburgaev, G.A. 1986. Staroslavianskii yazyk. Moskva: Prosveschenie.

Notes

\footnotetext{
${ }^{1}$ The author is grateful to Professor Alan Timberlake of UC Berkeley and Professor David Birnbaum of the University of Pittsburgh, who have kindly invited me to present at the Russian Primary Chronicle pre-conference held at Columbia University in April 2007. I am thankful to the pre-conference participants for their helpful comments on the early draft of this paper. Professors Alan Timberlake and Johanna Nichols of UC Berkeley offered insightful commentary on later drafts. The remaining mistakes are mine alone.

${ }^{2}$ Lixachev writes: "in... the PVL, the chronicler narrates history through play-acting, [he] enlivens the action sequence with dialogues... The Novgorodian chronicle is different. The short and energetic speeches of the Novgorodians are rarely dialogues. More often they are monologues, announcing decisions of prince or assembly" (Likhachev 1945: 114).

${ }^{3}$ For jako in OCS, see brief descriptions e.g. in Vaillant 1964: §258, Gorshkov 216-7, Xaburgaev 1986:238, in more detail Večerka 1989, 2001; for jako in Old Russian briefly Borkovskii and Kuznetsov 1963: 491, who write that though the conjunction jako was in literary use till the 17th century, it was "primarily bookish in character" from the
} 
earliest times; Lomtev also advocates this view, but notes that jako was widely used in a variety of Old Russian texts (Lomtev 1956, 507-8).

${ }^{4}$ Following those verbs, direct as well as indirect discourse can appear. A less clear context is that of hearing verbs with jako, e.g. Слышавъ же се Володимиръ ... яко Яропьлкъ уби Ольга... бъжа за море 'Volodimir, hearing that Jaropolk killed Oleg.. escaped overseas'. There are no instances of direct speech after hearing verbs with jako. Those contexts were excluded.

${ }^{5}$ A number of occurrences of jako cu m infinitivum could indeed be classified as indirect discourse; however, I am not comfortable making this statement before more data on this construction can be collected and analyzed. For a similar construction in Old French, que cum infinitivum, see Marnette 2005. Unfortunately, speech and thought representation in Old Russian have been understudied, with the notable exceptions of Collins 2001 and Lunde 2004. ${ }^{6}$ For classifying reported speech, I have only considered a shift in person deixis, since I have not found any instances of a shift in spatial and temporal deixis in the PVL. The examples of 'true' indirect discourse do not have any spatial or temporal deictic elements. Spatial and temporal deictic elements in the cases of jako recitativum do not undergo changes.

${ }^{7}$ Though arguably cbde 'here'; see note 5 on spatial deixis.

${ }^{8}$ There are some instances in the chronicle where voice, in the $1^{\text {st }}$ person, is most likely given to reporters different from the chronicler, thus: Въ сиже времена бысть дътищь вьвьржень въ СБтомль; его же дътища выволокоша рыболове въ неводъ, егоже позоровахомъ до вечера, и пакы вьвьргоша и въ воду. 'At this time there was a child thrown into Setoml; this child was caught by the fishers in their net, and we looked on it until the evening, and again [they] threw it into the water' (164: 14-22)

${ }^{9}$ I have noted earlier that distancing contexts such as political deception and pagan content could also be introduced without jako; however, statistically they are more likely to be introduced with jako - whereas biblical content is more likely to be introduced without jako.

${ }^{10}$ In my observation, Cross in his translation specifically converts jako recitativum to indirect discourse, but does not, as a rule, convert direct discourse without jako to indirect discourse.

${ }^{11}$ For example, the chronicler argues with some of his sources about the events as they truly happened. On the christening of Volodimir, the chronicle asserts that Крьсти же ся въ цьркъви святаго Василия.... Се же не съвьдуще право, глаголють, яко крьстиль ся есть вь Кыевъ, инии же рьша: въ Василевъ, друзии же инако ськазающе 'He was baptized in the church of St. Vasilii; those who do not know the truth, say that he was baptized in Kiev, others say in Vasil'ev, and yet others say differently'. 